\title{
GAS CHROMATOGRAPHY-MASS SPECTROMETRY ANALYSIS OF METHANOLIC LEAF EXTRACT OF CASSIA ANGUSTIFOLIA VAHL.
}

\author{
SHAHINA PARVEEN*, ANWAR SHAHZAD, ANAMICA UPADHYAY, VIKAS YADAV \\ Department of Botany, Plant Biotechnology Laboratory, Aligarh Muslim University, Aligarh, Uttar Pradesh, \\ India. Email: shahina.sony3@gmail.com
}

Received: 05 August 2016, Revised and Accepted: 30 August 2016

\section{ABSTRACT}

Objective: The leaves of Cassia angustifolia Vahl. are employed for the treatment of several human diseases. Therefore, the present study was undertaken to determine the phytocomponents present in the methanolic extract of the leaves by gas chromatography-mass spectrometry (GC-MS)

Methods: The collected leaf samples were dried and extracted in methanol. Screening of the extract was done by GC-MS which is an important technique for the separation and identification of different phytochemicals.

Results: The methanolic extract of the leaves of $C$. angustifolia revealed the presence of 45 different phytochemicals. The prevailing compounds were 1 butanol, 3 methyl acetate (area \% 7.47), 6, 6-dideutero-nonen-1-0l-3 (area \% 10.45), pentadecanoic acid (area \% 9.22), and squalene (area \% 12.30). Vitamin E (area \% 3.85) has also been found in the leaf extract. Some of the compounds possess biological activities.

Conclusions: It can be concluded from the present study that some of the identified phytochemicals could be responsible for the medicinal value or biological activity of the plant leaves.

Keywords: Senna, Leaf extract, Methanol, Gas chromatography-mass spectrometry, Phytochemicals, Vitamin E.

(C) 2016 The Authors. Published by Innovare Academic Sciences Pvt Ltd. This is an open access article under the CC BY license (http://creativecommons. org/licenses/by/4. 0/) DOI: http://dx.doi.org/10.22159/ajpcr.2016.v9s3.14512

\section{INTRODUCTION}

Each and every plant contains a certain specific type of chemical substances/compounds, which are produced during the normal growth and development of the plant body. These compounds are generally referred to as "phytochemicals" or sometimes also known as "secondary metabolites." These phytochemicals attribute to the medicinal value of the plant, and that's why, plants are being used to cure several diseases all over the world since time immemorial. Screening of active compounds present in the plant leads to the invention of new drugs which are used to cure various serious diseases such as cancer and Alzheimer's disease [1]. Medicinal plants are directly analyzed by gas chromatography-mass spectrometry (GC-MS) for their existing phytochemicals. GC-MS is an advanced technology to determine the presence of phytochemicals in plant tissues, which is extensively being utilized to screen the phytochemicals in medicinal plant species. Using GC-MS, it is now possible to identify volatile compounds with ease.

Cassia angustifolia Vahl. commonly known as "senna" is one of the most important medicinal shrubs belonging to family Fabaceae (Sub family: Caesalpinioideae). It is a native of Saudi Arabia and has been naturalized in India, Pakistan, and Egypt. The plant is a small shrub with usually 5-8 leaflets, lanceolate, glabrous, and axillary erect [2] Senna is widely used in the Ayurvedic and Unani system of medicine. Leaves and pods are used as a febrifuge in splenic enlargements, curing various diseases such as anemia, typhoid, jaundice, and cholera as well as reported to be an excellent blood purifier. It has also been employed in the treatment of constipation, amoebic dysentery, as an anthelmintic and a mild liver stimulant. Plant contains rhein, chrysophanol, emodin, and aloe-emodin-a water-soluble glycoside, besides these, derivatives of anthraquinone glycosides are also present in the leaves and pods which are commonly referred as "sennosides" [2]. Considering the importance of $C$. angustifolia, this study was undertaken for the first time to analyze the bioactive compounds present in the methanolic extract of leaves of this plant.

\section{METHODS}

Collection of plant samples and extraction procedure

Leaves of $C$. angustifolia were collected from Botanical Garden of the Department of Botany, AMU, Aligarh. Only mature and healthy leaves were harvested and collected in the early morning, packed in polythene bags, and kept at room temperature for further processing. Leaves were washed with tap water and shade dried for 5-6 days. About $5 \mathrm{~g}$ of air dried leaves were grounded to fine powder in a mortar pestle. About 5 $\mathrm{g}$ of powdered leaves of senna were extracted with $100 \mathrm{ml}$ methanol. It was left for $24 \mathrm{hrs}$ so that terpenoids and other constituents if present will get dissolved. The methanolic extract was then filtered through syringe filter, and the residue was removed.

\section{GC-MS analysis and identification of components}

The GC-MS analysis of the methanolic extract of the leaves of C. angustifolia was performed using a GC-MS of Hewlettt-Packard $6890 / 5973$ operating at $1000 \mathrm{eV}$ ionization energy, equipped with Agilent 7890A/5975 C GC HP-5. Capillary column (phenyl methyl siloxane, $25 \mathrm{~m} \times 0.25 \mathrm{~mm}$ i.d.) with Helium (He) was used as the carrier gas with split ratio $1: 5$. Oven temperature was $80^{\circ} \mathrm{C}(2$ minutes $)$ to $280^{\circ} \mathrm{C}$ at $1-40^{\circ} \mathrm{C} /$ minutes, detector temperature $250-280^{\circ} \mathrm{C}$, and carrier gas $\mathrm{He}(0.9 \mathrm{ml} /$ minutes). $2.0 \mu \mathrm{l}$ of respective diluted samples was manually injected in the splitless mode, with split ratio and with mass scan of 50-600 amu. Total running time of GC-MS is 40 minutes, the relative percentage of each extract constituent was expressed as a percentage with peak area normalization.

Interpretation on mass spectrum of GC-MS was done using the database of National Institute of Standards and Technology (NIST) and Wiley library for mass spectra, having more than 62000 patterns. The mass spectrum of the unknown component was compared with the spectrum of the known components stored in the NIST library. The name, molecular weight (MW), and structure of the components of the test materials were ascertained. 


\section{RESULTS}

In the present study, a total of 45 different phytocomponents have been found in the methanolic extract of the leaves of $C$. angutifolia. The identified compounds of senna, their retention indices (RT), molecular formulae, molecular structure, MW, and percentage composition (area \%) are given in Table 1. The results showed the presence of five

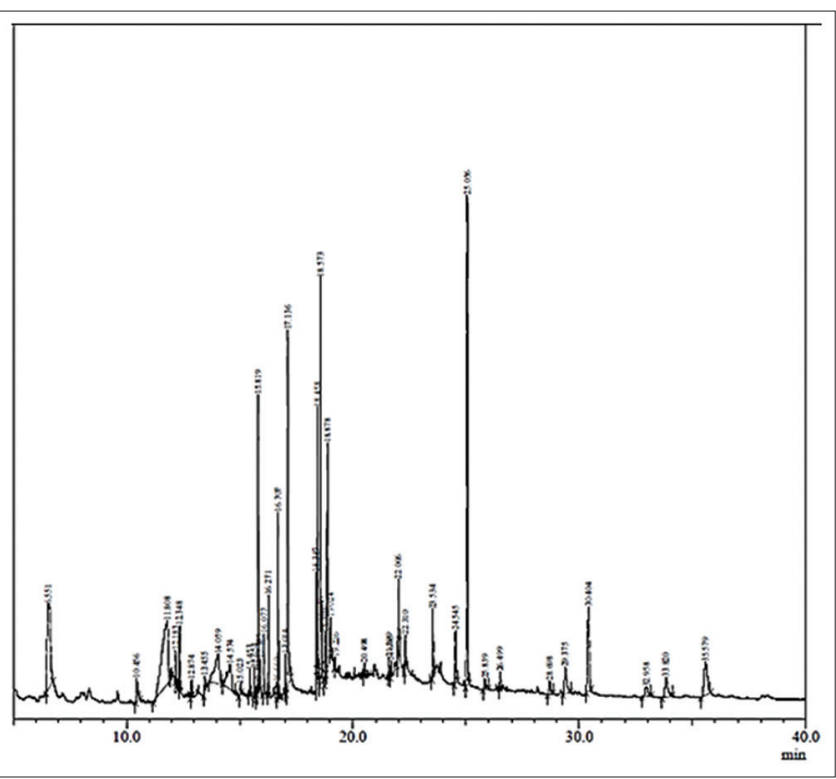

Fig. 1: Gas chromatography-mass spectrometry chromatogram of the methanolic leaf extract of Cassia angustifolia major components with maximum percentage $(12.3 \%)$ of squalene, followed by 6, 6-dideutero-nonen-1ol-3 (10.45\%), pentadecanoic acid (9.22\%), 1-butanol, 3 methyl-, acetate (7.47\%), and phytol (6.49\%). The leaf extract also showed the presence of tocopherol (Vitamin E, $3.85 \%$ with RT of 30.4 minutes) and gamma-tocopherol $(0.58 \%$ with RT of 28.6). The GC-MS chromatogram also shows 45 different peaks which confirm the presence of 45 compounds with their respective RT (Fig. 1). On comparison of the mass spectra of each phytochemical with the NIST and Wiley library, 45 phytoconstituents were characterized and identified. The individual fragmentation of five major components is illustrated in Fig. 2 (A-E). Some of the identified components possess biological activities which are listed in Table 2. These biological activities are based on Dr. Duke's Phytochemical and Ethnobotanical Databases by Dr. Jim Duke of the Agricultural Research Service USDA [3]

\section{DISCUSSION}

GC-MS chromatogram of the methanolic extract of the leaves of C. angustifolia showed the presence of 45 different phytocomponents. From observations and comparison with the mass spectrum of each constituent with NIST and Wiley library, it was found that squalene, 6,6-Dideutero-Nonen-1-Ol-3, pentadecanoic acid, 1 butanol, 3 methyl acetate, and phytol are the major components (Fig. 2). Besides these compounds, vitamin E (3.85\%), gamma-tocopherol (0.58\%), and several other antioxidants are also present.

Squalene, which constitutes about $12.3 \%$, is a hydrocarbon which is used in cosmetics, as an immunologic adjuvant in vaccines and may be used as a chemopreventive substance that protects people from cancer $[4,5]$ However, pentadecanoic acid, which is $9.22 \%$ in the tested extract, is a saturated fatty acid and is rare in nature but found at the level of $1.2 \%$ in the milk of cows [6]. Phytol is an acyclic diterpene alcohol that can be used as a precursor for the manufacture of synthetic forms of vitamin

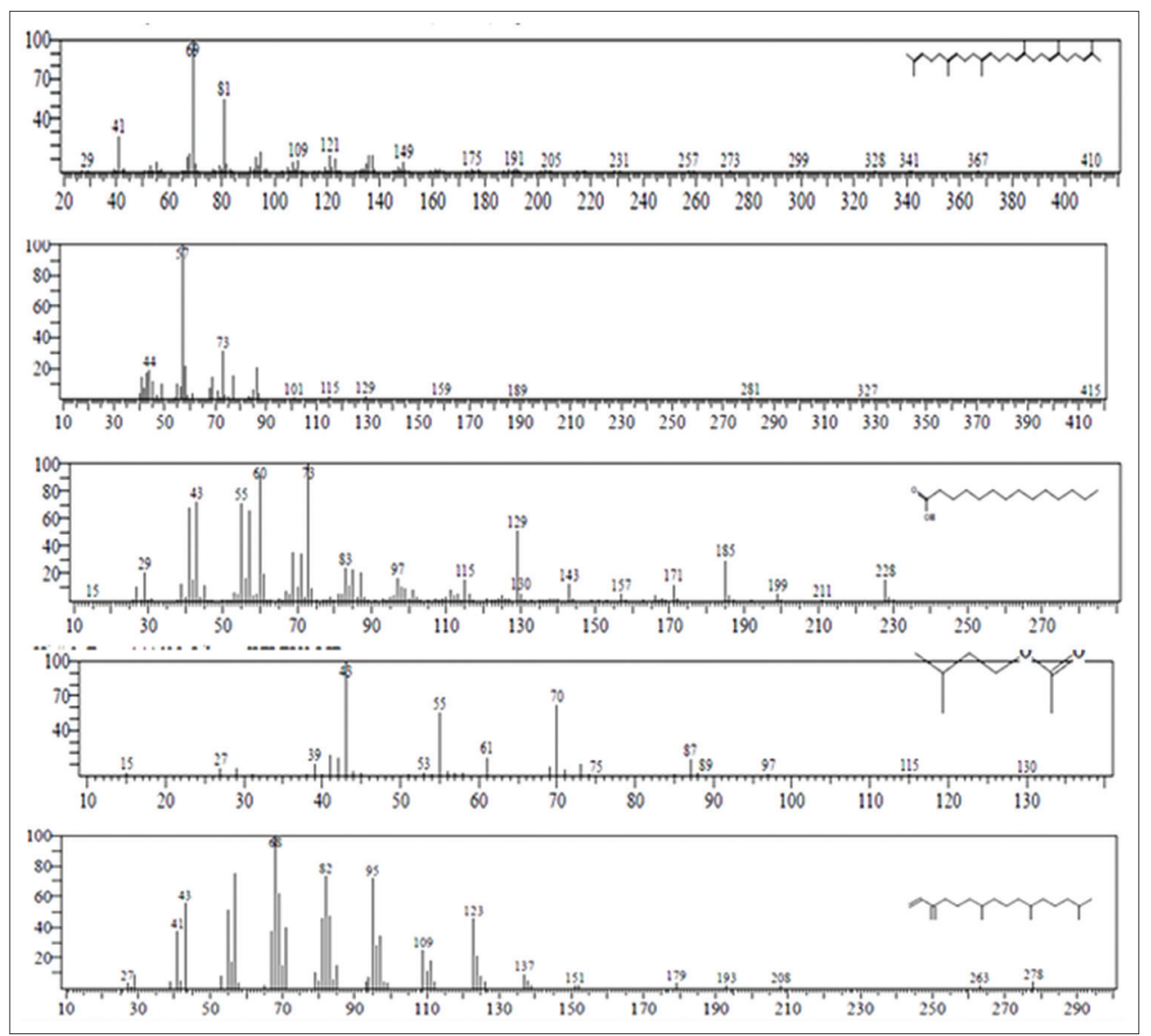

Fig. 2: Mass spectrum of (A) squalene (area \% 12.30), (B) 6,6-dideutero-nonen-1-0l-3 (area \% 10.45), (C) pentadecanoic acid (area \% 9.22), (D) 1 butanol, 3 methyl acetate (area \% 7.47), and (E) phytol (6.49\%) 
Table 1: Phytocomponents detected in the methanolic leaf extract of Cassia angustifolia

\begin{tabular}{|c|c|c|c|c|c|}
\hline Name of the compounds & RT & $\begin{array}{l}\text { Molecular } \\
\text { formula }\end{array}$ & Molecular structure & MW & $\begin{array}{l}\text { Area } \\
\%\end{array}$ \\
\hline 1-butanol, 3-methyl-, acetate & 6.551 & $\mathrm{C}_{7} \mathrm{H}_{14} \mathrm{O}_{2}$ & & 130 & 7.47 \\
\hline 5-oxo-pyrrolidine-2-carboxylic acid methyl & 10.456 & $\mathrm{C}_{6} \mathrm{H}_{9} \mathrm{NO}_{3}$ & & 143 & 0.84 \\
\hline 6,6-dideutero-Nonen-1-Ol-3 & 11.808 & $\mathrm{C}_{9} \mathrm{H}_{16} \mathrm{D}_{2} \mathrm{O}$ & & 144 & 10.45 \\
\hline Phenol, 2,4-bis (1,1-dimethylethyl)- & 12.183 & $\mathrm{C}_{14} \mathrm{H}_{22} \mathrm{O}$ & & 206 & 0.57 \\
\hline Benzoic acid, 4-ethoxy-, ethyl ester & 12.348 & $\mathrm{C}_{11} \mathrm{H}_{14} \mathrm{O}_{3}$ & & 194 & 0.99 \\
\hline Phenol, (1,1-dimethylethyl)-4-methoxy- & 12.874 & $\mathrm{C}_{11} \mathrm{H}_{16} \mathrm{O}_{2}$ & & 180 & 0.31 \\
\hline benzene, 1,2,4-trimethoxy-5-(1-propenyl)-, (Z)- & 13.455 & $\mathrm{C}_{12} \mathrm{H}_{16} \mathrm{O}_{3}$ & & 208 & 0.25 \\
\hline Mome inositol & 14.059 & $\mathrm{C}_{7} \mathrm{H}_{14} \mathrm{O}_{6}$ & & 194 & 3.93 \\
\hline Mome Inositol & 14.574 & $\mathrm{C}_{7} \mathrm{H}_{14} \mathrm{O}_{6}$ & & 194 & 2.77 \\
\hline
\end{tabular}


Table 1: (Continued)

\begin{tabular}{|c|c|c|c|c|c|}
\hline Name of the compounds & RT & $\begin{array}{l}\text { Molecular } \\
\text { formula }\end{array}$ & Molecular structure & MW & $\begin{array}{l}\text { Area } \\
\%\end{array}$ \\
\hline Tetradecanoic acid & 15.023 & $\mathrm{C}_{14} \mathrm{H}_{28} \mathrm{O}_{2}$ & & 228 & 0.18 \\
\hline 3-Heptadecanol & 15.453 & $\mathrm{C}_{17} \mathrm{H}_{36} \mathrm{O}$ & & 256 & 0.36 \\
\hline Isopropyl tetradecanoate & 15.654 & $\mathrm{C}_{17} \mathrm{H}_{34} \mathrm{O}_{2}$ & & 270 & 0.38 \\
\hline (2e)-3,7,11,15-tetramethyl-2-hexadecene & 15.761 & $\mathrm{C}_{20} \mathrm{H}_{40}$ & & 280 & 0.15 \\
\hline 2,6,10-trimethyl, 14-ethylene-14-pentadecne & 15.819 & $\mathrm{C}_{20} \mathrm{H}_{38}$ & & 278 & 4.24 \\
\hline (2e)-3,7,11,15-tetramethyl-2-hexadecene & 15.885 & $\mathrm{C}_{20} \mathrm{H}_{40}$ & & 280 & 0.36 \\
\hline 3,7,11,15-Tetramethyl-2-Hexadecen-1-Ol & 16.077 & $\mathrm{C}_{20} \mathrm{H}_{40} \mathrm{O}$ & & 296 & 0.99 \\
\hline $\begin{array}{l}\text { 2-Hexadecen-1-Ol, 3,7,11,15-tetramethyl-, [R-[R*, } \\
\mathrm{R}^{*} \text {-(E)]]- }\end{array}$ & 16.271 & $\mathrm{C}_{20} \mathrm{H}_{40} \mathrm{O}$ & & 296 & 1.42 \\
\hline Z-9-Tetradecen-1-Ol formate & 16.660 & $\mathrm{C}_{15} \mathrm{H}_{28} \mathrm{O}_{2}$ & & 240 & 0.13 \\
\hline Hexadecanoic acid, methyl ester & 16.707 & $\mathrm{C}_{17} \mathrm{H}_{34} \mathrm{O}_{2}$ & & 270 & 2.46 \\
\hline Benzene, 1,1'-sulfonylbis- & 17.014 & $\mathrm{C}_{12} \mathrm{H}_{10} \mathrm{O}_{2} \mathrm{~S}$ & & 218 & 0.61 \\
\hline Pentadecanoic acid & 17.136 & $\mathrm{C}_{15} \mathrm{H}_{30} \mathrm{O}_{2}$ & & 242 & 9.22 \\
\hline 9,12-Octadecadienoic acid (Z, Z)-, Methyl Ester & 18.387 & $\mathrm{C}_{19} \mathrm{H}_{34} \mathrm{O}_{2}$ & & 294 & 1.42 \\
\hline 9,12,15-Octadecatrienoic acid, methyl ester, (Z, Z, Z)- & 18.458 & $\mathrm{C}_{19} \mathrm{H}_{32} \mathrm{O}_{2}$ & & 292 & 5.32 \\
\hline Phytol & 18.573 & $\mathrm{C}_{20} \mathrm{H}_{40} \mathrm{O}$ & & 296 & 6.49 \\
\hline Methyl stearate & 18.650 & $\mathrm{C}_{19} \mathrm{H}_{38} \mathrm{O}_{2}$ & & 298 & 0.63 \\
\hline 9,12-Octadecadienoic Acid (Z, Z)- & 18.797 & $\mathrm{C}_{18} \mathrm{H}_{32} \mathrm{O}_{2}$ & & 280 & 1.17 \\
\hline 9,12,15-octadecatrienoic acid, (Z, Z, Z)- & 18.878 & $\mathrm{C}_{18} \mathrm{H}_{30} \mathrm{O}_{2}$ & & 278 & 6.32 \\
\hline Octadecanoic acid & 19.024 & $\mathrm{C}_{18} \mathrm{H}_{36} \mathrm{O}_{2}$ & & 284 & 0.79 \\
\hline 9,12-Octadecadienoic acid (Z, Z)-, methyl ester & 19.226 & $\mathrm{C}_{19} \mathrm{H}_{34} \mathrm{O}_{2}$ & & 294 & 0.20 \\
\hline 2-Ethylhexyl (2e)-3-(4-methoxyphenyl)-2-propenoate & 20.498 & $\mathrm{C}_{18} \mathrm{H}_{26} \mathrm{O}_{3}$ & & 290 & 0.17 \\
\hline $\begin{array}{l}\text { 3-Cyclopentylpropionic acid, 2-dimethylaminoethyl } \\
\text { ester }\end{array}$ & 21.599 & $\mathrm{C}_{12} \mathrm{H}_{23} \mathrm{NO}_{2}$ & & 213 & 0.27 \\
\hline
\end{tabular}


Table 1: (Continued)

\begin{tabular}{|c|c|c|c|c|c|}
\hline Name of the compounds & RT & $\begin{array}{l}\text { Molecular } \\
\text { formula }\end{array}$ & Molecular structure & MW & $\begin{array}{l}\text { Area } \\
\%\end{array}$ \\
\hline Oxalic acid, monoamide, $\mathrm{N}$-allyl-, tetradecyl ester & 21.690 & $\mathrm{C}_{19} \mathrm{H}_{35} \mathrm{NO}_{3}$ & & 325 & 0.24 \\
\hline $\begin{array}{l}\text { Hexadecanoic acid, 2-hydroxy-1-(hydroxymethyl) } \\
\text { ethyl ester }\end{array}$ & 22.006 & $\mathrm{C}_{19} \mathrm{H}_{38} \mathrm{O}_{4}$ & & 330 & 1.49 \\
\hline 1,2-Benzenedicarboxylic acid & 22.310 & $\mathrm{C}_{24} \mathrm{H}_{38} \mathrm{O}_{4}$ & 0 & 390 & 0.48 \\
\hline Pentacosane & 23.534 & $\mathrm{C}_{25} \mathrm{H}_{52}$ & & 352 & 1.24 \\
\hline 9-octadecenamide & 24.545 & $\mathrm{C}_{18} \mathrm{H}_{35} \mathrm{NO}$ & & 281 & 1.41 \\
\hline Squalene & 25.056 & $\mathrm{C}_{30} \mathrm{H}_{50}$ & & 410 & 12.30 \\
\hline Tetracontane & 25.839 & $\mathrm{C}_{40} \mathrm{H}_{82}$ & $m$ & 562 & 0.41 \\
\hline Neryl linalool isomer & 26.499 & $\mathrm{C}_{20} \mathrm{H}_{34} \mathrm{O}$ & & 290 & 0.45 \\
\hline Gamma-tocopherol & 28.698 & $\mathrm{C}_{28} \mathrm{H}_{48} \mathrm{O}_{2}$ & & 416 & 0.58 \\
\hline 1-Heptacosanol & 29.375 & $\mathrm{C}_{27} \mathrm{H}_{56} \mathrm{O}$ & & 396 & 1.59 \\
\hline Vitamin E & 30.404 & $\mathrm{C}_{29} \mathrm{H}_{50} \mathrm{O} 2$ & & 430 & 3.85 \\
\hline Ergost-5-En-3-Ol, (3.Beta.,24r)- & 32.958 & $\mathrm{C}_{28} \mathrm{H}_{48} \mathrm{O}$ & & 400 & 0.69 \\
\hline Stigmasta-5,22-Dien-3-0l & 33.820 & $\mathrm{C}_{29} \mathrm{H}_{48} \mathrm{O}$ & & 412 & 1.67 \\
\hline Stigmast-5-En-3-Ol, (3.Beta.)- & 35.579 & $\mathrm{C}_{29} \mathrm{H}_{50} \mathrm{O}$ & & 414 & 2.74 \\
\hline
\end{tabular}

E [7] and vitamin K [8]. It is used in shampoos, cosmetics, toilet soaps, fragrance industry, household cleanser, and detergents [9]. Some of the antioxidants found to be present in senna leaf extract are tetradecanoic acid (synonym: Myristic acid), hexadecanoic acid, heptadecanoic acid, squalene (synonym: 2,6,10,14,18,22-tetracosahexaene), vitamin E (synonym: D-alpha-tocopherol), gamma-tocopherol (synonym: 7,8-dimethyltocol), campesterol (synonym: Ergost-5-en-3.beta.-ol), and $\beta$-stigmasterol (synonym: Stigmast-5-En-3-Ol, [3.Beta.]). In our study, the leaf extract of senna contains $2.74 \% \beta$-sitosterol. However, Rastogi and Mehoratra [10] reported that the plant contains only $0.33 \%$ $\beta$-sitosterol. Some of the components such as hexadecanoic acid methyl ester, phytol, 9,12-octadecanoic acid (Z,Z)-, 9,12,15-ooctadecatrienoic acid (Z,Z,Z)-, octadecanoic acid, and squalene have also been reported in the methanolic leaf extract of Cassia alata [11]. The methanolic leaf extract of Lannea kerstingii and Nauclea diderrichii also reported to contain hexadecanoic acid methyl ester and pentacosane [12]. 
Table 2: Biological properties of some of the phytocomponents identified in the methanolic extracts of Cassia angustifolia by GC-MS

\begin{tabular}{|c|c|}
\hline Name of compounds & \\
\hline $\begin{array}{l}\text { 2,6,10,14,18,22-tetracosahexaene, } \\
\text { 2,6,10,15,19,23-hexamethyl-/squalene } \\
\text { Pentadecanoic acid/myristic acid } \\
\text { 3,7,11,15-tetramethyl-2-hexadecen-1-ol 2-pentadecanone, } \\
\text { 6,10,14-trimethyl/phytol } \\
\text { Gamma-tocopherol }\end{array}$ & \\
\hline Vitamin E & \\
\hline $\begin{array}{l}\text { Ergost-5-en-3.beta.-ol/campesterol } \\
\text { Stigmasta-5,22-dien-3.beta.-ol, (3.beta.,22E)-/stigmasterol }\end{array}$ & \\
\hline $\begin{array}{l}\text { *Source: Dr. Duke's phytochemical and ethnobotanical database ww } \\
\text { spectrometry }\end{array}$ & \\
\hline CONCLUSION & \\
\hline $\begin{array}{l}\text { Screening of leaf extract of } C \text {. angustifolia by GC-MS re } \\
\text { presence of } 45 \text { different phytochemicals. The study was unde } \\
\text { the first time, till date no information was available on GC-MS } \\
\text { senna. The analysis showed the presence of highly valuable } \\
\text { which could be used by various pharmaceutical or drug com } \\
\text { the development of new medicines. }\end{array}$ & \\
\hline
\end{tabular}

\section{ACKNOWLEDGMENTS}

Author, Dr. Shahina Parveen gratefully acknowledges the financial assistance provided by the Department of Science and Technology (DST) - Science and Engineering Research Board (SERB), Government of India, New Delhi, for the award of Young Scientist Project (Vide No. SB/ YS/LS - 156/2013). Authors are also thankful to AIRF, JNU, New Delhi, for providing GC-MS facility.

\section{REFERENCES}

1. Mukherjee PK, Kumar V, Houghton PJ. Screening of Indian medicinal plants for acetylcholinesterase inhibitory activity. Phytother Res 2007;21(12):1142-5.

2. Anonymous. The Wealth of India, Raw Materials. Vol. 3. New Delhi: CSIR; 1992. p. 354-63.

3. Duke J. Phytochemical and Ethnobotanical Databases. U.S. Department of Agriculture, Agricultural Research Service; 1992-2016. Home Page.

\section{Biological properties*}

Antibacterial, antioxidant, cancer-preventive, antitumor, immunostimulant, perfumery, pesticide, sunscreen

Antioxidant, lubricant, hypercholesterolemic, cancer-preventive, cosmetic

Cancer preventive

Anticancer, antioxidant, antitumor, anti-inflammatory, hypocholesterolemic, cardioprotective

Antiaging, antialzheimeran, antidermatitic, antidiabetic, antioxidant, antitumor, cancer-preventive, hypocholesterolemic, immunostimulant Antioxidant, hypocholesterolemic

Antihepatotoxic, antiviral, antioxidant,cancerpreventive, hypocholesterolemic 